\title{
Alih Fungsi Lahan Pertanian di Kawasan Jalan Hertasning Baru Kelurahan Kassi-Kassi Kota Makassar
}

\author{
Change of Function of Agricultural Land in the New Hertasning Road Area Kassi-Kassi \\ Village, Makassar City
}

\author{
Regita Cahyani Mokoginta ${ }^{1}$, Syafri ${ }^{1,2}$, Jufriadi ${ }^{1}$ \\ ${ }^{1}$ Program Studi Perencanaan Wilayah dan Kota, Fakultas Teknik, Universitas Bosowa \\ ${ }^{2}$ Program Studi Pascasarjana Perencanaan Wilayah dan Kota, Fakultas Teknik, Universitas Bosowa \\ Email : Regitamokoginta97@gmail.com
}

\section{Artikel info}

\section{Artikel history:}

Diterima; 14-03-2021

Direvisi: 25-03-2021

Disetujui; 19-04-2021
Abstract.This study aims to analyze and determine the significant factors affecting the conversion of agricultural land along Jalan Hertasning Baru Makassar City. This study consisted of 4 variables, namely socio-economy, land users, accessibility and spatial designation. By using chi square analysis and contingency $C$ to get the factors that most influence the conversion of function, and then using SWOT analysis to create alternative strategies in controlling land use change.

\begin{abstract}
Abstrak. Penelitian ini bertujuan untuk Untuk menganalisis dan mengetahui faktor-faktor yang signifikan mempengaruhi alih fungsi lahan pertanian di sepanjang Jalan Hertasning Baru Kota Makassar. Penelitian ini terdiri dari 4 variabel yaitu sosial ekonomi, pemakai lahan, aksesibilitas dan peruntukan ruang. Dengan menggunakan analisis chi square dan kontingensi $\mathrm{C}$ untuk mendapatkan faktor - faktor yang paling mempengaruhi alih fungsi, dan selanjutnya menggunakan analisis SWOT untuk menciptakan alternatif strategi dalam mengendalikan alih fungsi lahan.
\end{abstract}

\author{
Keywords: \\ Alih Fungsi Lahan, \\ makassar, kassi- \\ kassi, pertanian
}

Coresponden author:

Email: Regitamokoginta97@gmail.com

artikel dengan akses terbuka dibawah lisensi CC BY -4.0

\section{PENDAHULUAN}

Wilayah perkotaan akan berjalan sejajar dengan ekspansi kota inti ke arah pinggiran yang diawali dengan perubahan guna lahan pertanian produktif kearah industrial perkotaan. Perubahan guna lahan berciri perubahan pemanfaatan ruang yang diindikasikan berdampak pada perubahan struktur sosial, proses sosial dan pola kultural komunitas perkotaan.

Salah satu program pemerintah untuk mensejahterakan masyarakat adalah pembangunan. Dari dulu hingga sekarang pembangunan fisik dan non fisik selalu menjadi fokus utama bagi pemerintah, diantaranya yaitu infrastruktur jalan, jembatan, subsidi pendidikan, dll.

Pembangunan pada hakikatnya adalah proses perubahan yang terjadi secara terus-menerus melalui upaya yang dilakukan dengan terencana. Indonesia merupakan negara berkembang yang berusaha untuk mengembangkan dirinya agar dapat menuju ke arah keadaan yang dianggap lebih baik. guna untuk memenuhi kebutuhan masyarakat secara menyeluruh modal dan potensi sumber daya dalam negeri perlu dimanfaatkan secara optimal. Berkembangnya zaman membuat manusia agar dapat mempertahankan keberadaannya dalam kehidupan. Manusia sebagai makhluk sosial pasti akan mengalami perbedaan keadaan sosial dari waktu sebelumnya ke waktu sekarang maupun masa yang akan datang. perubahan sosial dan perubahan tatanan masyarakat cepat atau lambat dapat berlangsung dengan sendirinya nya tentu saja dengan memperhatikan faktor-faktor pendukung sekaligus penghambatnya. perubahan sosial yang berdampak pada pembangunan sosial masyarakat tentunya tak lepas dari peran pembangunan ekonomi karena pembangunan ekonomi yang maju akan menghasilkan pembangunan sosial yang maju pula. 
Faktor sosial budaya, juga menjadi salah satu isu yang mempengaruhi terjadinya alih fungsi lahan pertaniaan, seperti yang terjadi di Hertasning banyak penduduk beranggapan bahwa mata pencaharian di bidang pertaniaan tidak dapat meningkatkan taraf hidup di masa sekarang tidak seperti pada masa lalu yang disebabkan karena rendahnya harga jual hasil produksi pertaniaan dibanding usaha disektor non-pertanian perkembangan perkembangan kawasan mamminasata menunjukkan kemajuan yang pesat seiring dengan bertambahnya juga jumlah penduduk dan semakin besarnya kegiatan pembangunan dari berbagai sektor serta tuntutan 3 kebutuhan dari berbagai aspek baik itu ekonomi, sosial dan budaya telah mengakibatkan meningkatnya Aktivitas penduduk di perkotaan. Akibat dari meningkatnya kebutuhan ruang perkotaan yang besar maka ketersediaan ruang di dalam kota pun dapat dikatakan sangat terbatas, maka tinggi pula kebutuhan ruang untuk tempat tinggal, hal inilah yang mengakibatkatkan orang-orang cenderung mengambil ruang di daerah pinggiran kota guna merealisasikan suatu pembangunan.

\section{METODE}

\subsection{Lokasi Penelitian dan Waktu Penelitian}

Adapaun lokasi penelitian yang diambil dalam kegiatan penelitian ini adalah sepanjang Jalan Hertasning Baru Kelurahan Kassi-kassi Kota Makassar Waktu penelitian merupakan batasan waktu yang digunakan dalam melakukan penelitian. Adapun waktu yang dibutuhkan dalam penelitian \pm 1-2 bulan dalam Penelitian.

\subsection{Jenis dan Sumber Data}

Jenis dan sumber data dibutuhkan 2 jenis data yaitu Data primer, yaitu data yang diperoleh langsung dari hasil penelitian di lapangan yang berhubungan dengan faktor - faktor yang mempengaruhi alih fungsi lahan pertanian Yang ada berdasarkan kondisi yang ada di lapangan dan hasil dari wawancara dengan masyarakat setempat dan data sekunder yaitu data yang diperoleh dari instansi terkait misaguna untuk mengetahui data kuantitatif objek penelitian dimana data ini bersumber dari beberapa instansi terkait misalnya Badan Pusat Statistik dan lain - lain. Jenis data yang di butuhkan mencakup letak geografi wilayah, jumlah penduduk, luas wilayah, luas persawahan, dll.

\subsection{Metode Pengumpulan Data}

Adapun metode pengumpulan data pada penelitian ini yaitu Observasi yang berfungsi untuk melakukan pencarian data dengan mengidentifikasi data melalui pengukuran serta pengambilan data secara langsung di lapangan. Quisioner dan wawancara yang dimana adalah suatu bentuk komunikasi verbal dan pengumpulan data yang bertujuan untuk memperoleh informasi

\subsection{Populasi dan Sampel}

Populasi yang peneliti gunakan dalam penelitian untuk mengetahui factor penyebab alih fungsi lahan yaitu di kawasan Jalan Hertasning Baru Kelurahan Kassi-kassi Kota Makassar sedangkan Sampel adalah sebagian atau wakil populasi yang di teliti ditentukan berdasarkan rumus slovin Adapun pengambilan sampel menggunakan rumus slovin, 1960 dalam Alimuddin Tuwu (2006:161). yang di harapkan keberadaannya dapat mewakili atau menggambarkan ciri-ciri dan keberadaan populasi yang sebenarnya dengan sampel yang berjumlah 100 orang dengan kriteria umur 17 tahun ke atas.

\subsection{Variabel Penelitian}

Haig (1927) dalam Aryunto (2011) bahwa alih fungsi lahan Yang terjadi pada wilayah kota diakibatkan oleh persaingan diantara para pemakaian lahan ruang yang tertinggi, aktivitas sosial ekonomi, dan Aksesibilitasnya.

Dari teori serta analisis yang digunakan oleh peneliti maka variabel dalam penelitian ini yaitu Aktifitas sosial ekonomi, Pemakai lahan, Aksesibilitas, dan Peruntukan Ruang

\subsection{Pendekatan Analisis}

Pendekatan analisis yang digunakan dalam penelitian ini yaitu Pendekatan Kuantitatif. metode penelitian kuantitatif dapat diartikan sebagai metode penelitian yang berlandaskan pada filsafat positivisme, digunakan untuk meneliti pada populasi atau sampel tertentu. Pada pendekatan analisis ini, pengumpulan data dilakukan dengan menggunakan instrumen penelitian, analisis data bersifat kuantitatif/statistik dengan tujuan untuk menguji hipotesis yang telah ditetapkan (Sugiyono, 2012: 7).

\subsection{Metode Analisis}

Dalam penelitian yang dilakukan untuk mengetahui faktor apa saja yang menyebabkan perubahan pemanfaatan ruang di sepanjang jalan hertasning Kelurahan Kassi-kassi serta bagaiamana bentuk pengendalian Tata Ruang Kota dalam mengatasi alih fungsi ruang di sepanjang Jalan Hertasning kelurahan Kassi maka alat analisis yang akan digunakan adalah Analisis CHI-kuadrat, Koefisien Kontingensi C, dan Analisis SWOT. 
Chi Square disebut juga dengan Kai Kuadrat. Chi Square adalah salah satu jenis uji komparatif non parametris yang dilakukan pada dua variabel, di mana skala data kedua variabel adalah nominal. (Apabila dari 2 variabel, ada 1 variabel dengan skala nominal maka dilakukan uji chi square dengan merujuk bahwa harus digunakan uji pada derajat yang terendah).

Uji chi square merupakan uji non parametris yang paling banyak digunakan. Namun perlu diketahui syaratsyarat uji ini adalah: frekuensi responden atau sampel yang digunakan besar, sebab ada beberapa syarat di mana chi square dapat digunakan yaitu:

1. Tidak ada cell dengan nilai frekuensi kenyataan atau disebut juga Actual Count (F0) sebesar 0 (Nol).

2. Apabila bentuk tabel kontingensi 2 X 2, maka tidak boleh ada 1 cell saja yang memiliki frekuensi harapan atau disebut juga expected count ("Fh") kurang dari 5.

3. Apabila bentuk tabel lebih dari $2 \times 2$, misak $2 \times 3$, maka jumlah cell dengan frekuensi harapan yang kurang dari 5 tidak boleh lebih dari $20 \%$.

Untuk memahami apa itu "cell", lihat tabel di bawah ini:

Tabel 1. Koefisien Kontingensi

\begin{tabular}{ccccc}
\hline Pendidikan & \multicolumn{3}{c}{ pekerjaan } & \multirow{2}{*}{ Total } \\
\cline { 2 - 4 } & 1 & 2 & \\
\hline 1 & $\mathrm{a}$ & $\mathrm{b}$ & $\mathrm{a}+\mathrm{b}$ \\
\hline 2 & $\mathrm{c}$ & $\mathrm{d}$ & $\mathrm{c}+\mathrm{d}$ \\
\hline 3 & $\mathrm{e}$ & $\mathrm{f}$ & $\mathrm{e}+\mathrm{f}$ \\
\hline Total & $\mathrm{a}+\mathrm{c}+\mathrm{e}$ & $\mathrm{b}+\mathrm{d}+\mathrm{f}$ & $\mathrm{N}$ \\
\hline
\end{tabular}

Uji ini sangatlah erat kaitannya dengan uji chi-square. Sebab berdasarkan rumus uji koefisien ini, bahwa tidaklah mungkin koefisien ini dapat dihitung tanpa terlebih dahulu mengetahu nilai dari chi-square. Jadi, logikanya adalah hitung terlebih dahulu chi-square, baru kemudian hitung koefisien kontingensi.

Adapun rumus yang digunakan untuk menghitung Koefisien Kontingensi adalah sebagai berikut :

$c=\sqrt{\frac{x^{2}}{x^{2}+n}}$

Analisis SWOTAnalisis SWOT adalah Analisis yang digunakan untuk melakukan analisis strategis. menurut Drs. Robert Simbolon, MPA (1999), SWOT suatu alat analisis yang efektif dalam jam membantu menstrukturkan masalah, ah itu mah dengan analisis lingkungan strategis, yang lingkungan eksternal. ada 4 unsur yang terdapat dalam lingkungan internal dan eksternal ini yaitu kekuatan (strengths), kelemahan-kelemahan (weaknesses),peluang-peluang (opportunities) dan ancaman-ancaman (threats).

Tabel 2. Model analisis faktor strategi internal (ifas)

\begin{tabular}{ccccc}
\hline No & Faktor-Faktor Strategis & Bobot & Nilai & Bobot x Nilai \\
\hline 1 & $\begin{array}{c}\text { Kekuatan: } \\
\text { (faktor-faktor yang } \\
\text { menjadi kekuatan) }\end{array}$ & (Professional Judgement) & (Professional Judgement) & $\begin{array}{c}\text { (Jumlah perkalian bobot dengan nilai } \\
\text { pada setiap faktor dari kekuatan) }\end{array}$ \\
\hline & Jumlah & (Jumlah bobot kekuatan) & (Jumlah nilai kekuatan) & (Jumlah bobot X nilai kekuatan) \\
\hline 2 & $\begin{array}{c}\text { Kelemahan: } \\
\text { (faktor-faktor yang } \\
\text { menjadi kelemahan) }\end{array}$ & (Professional Judgement) & (Professional Judgement) & $\begin{array}{c}\text { (Jumlah perkalian bobot dengan nilai } \\
\text { pada setiap faktor dari kelemahan) }\end{array}$ \\
& Jumlah & (Jumlah bobot kelemahan) & (Jumlah nilai kelemahan) & (Jumlah bobot X nilai kelemahan)
\end{tabular}

Sumber: Diklat Spama, 2000

Tabel 3. Model analisis faktor strategi eksternal (Efas)

\begin{tabular}{|c|c|c|c|c|}
\hline No & Faktor-Faktor Strategis & Bobot & Nilai & Bobot x Nilai \\
\hline 1 & $\begin{array}{l}\text { Peluang: } \\
\text { (faktor-faktor yang } \\
\text { peluang) }\end{array}$ & $\begin{array}{l}\text { (Professional } \\
\text { Judgement) }\end{array}$ & $\begin{array}{l}\text { (Professional } \\
\text { Judgement) }\end{array}$ & $\begin{array}{l}\text { (Jumlah perkalian bobot dengan } \\
\text { nilai pada setiap faktor dari } \\
\text { peluang) }\end{array}$ \\
\hline Jumlah & & (Jumlah bobot peluang) & (Jumlah nilai peluang) & (Jumlah bobot X nilai peluang) \\
\hline 2 & $\begin{array}{l}\text { Ancaman: } \\
\text { (faktor-faktor yang menjadi } \\
\text { ancaman) }\end{array}$ & $\begin{array}{l}\text { (Professional } \\
\text { Judgement) }\end{array}$ & $\begin{array}{l}\text { (Professional } \\
\text { Judgement) }\end{array}$ & $\begin{array}{l}\text { (Jumlah perkalian bobot dengan } \\
\text { nilai pada setiap faktor dari } \\
\text { ancaman) }\end{array}$ \\
\hline Jumlah & & (Jumlah bobot ancaman) & (Jumlah nilai ancaman) & (Jumlah bobot X nilai ancaman) \\
\hline
\end{tabular}

Sumber: Diklat Spama, 2000 


\section{HASIL DAN PEMBAHASAN}

\subsection{Gambaran Umum Kawasan Hertasning}

Secara administratif, kawasan hertasning termasuk dalam wilayah Kelurahan kassi-kassi Kecamatan rappocini Kota Makassar. Secara geografis berbatasan dengan Kecamatan Manggala di Sebelah Utara, Kabupaten Gowa di sebelah Timur, kelurahan mapala di sebelah Selatan, Kecamatan panakkukang di sebelah Barat Kelurahan Kassi-kassi merupakan kelurahan yang terkecil di kelurahan rappocini yakni dengan luas wilayah $0,80 \mathrm{~km}^{2}$,

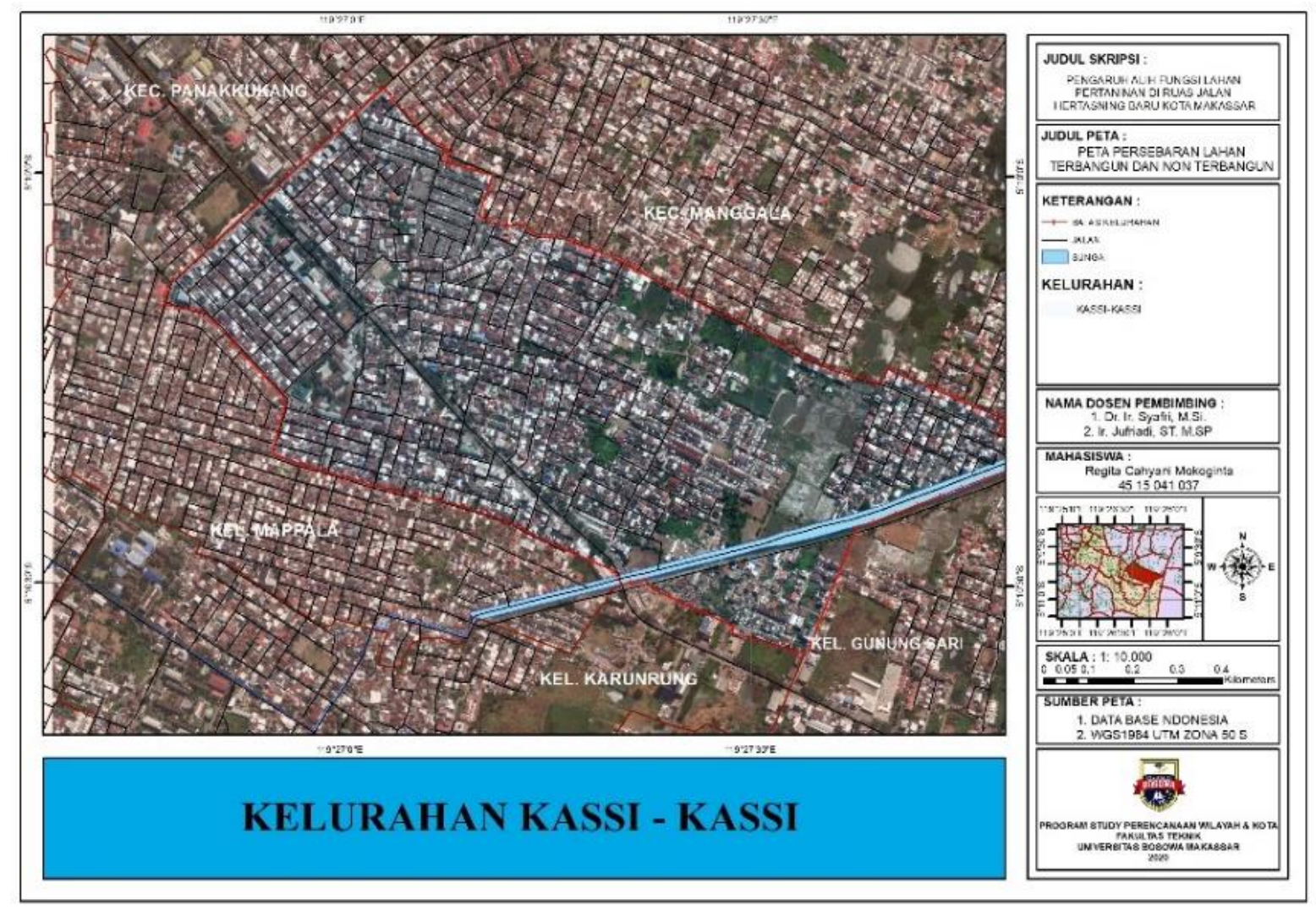

Gambar 1. Peta Lokasi Penelitian

\subsection{PEMBAHASAN}

Kebutuhan akan tempat tinggal yang terus meningkat menjadikan tingkat pengalih fungsian lahan menjadi permasalahan yang sulit untuk diselesaikan. Lahan yang kerap kali menjadi korban dalam memenuhi kebutuhan akan tempat tinggal tersebut tentunya tidak lain adalah lahan pertanian.

Alih fungsi lahan saat ini sering terjadi dimana mana karena begitu banyaknya tuntutan kebutuhan akan tempat tinggal akhirnya petanipun tergiur untuk menjualnya dengan harga tinggi tanpa mempedulikan dampak yang akan terjadi di masa depan.

Sehingga pembangunan dilakukan tanpa perlu mengesampingkan bidang pertanian sebagai yang menyediaakan bahan pangan dan menjadikan sumber mata pencaharian bagi sebagian besar masyarakat, dapat kita lihat dari peta pemakaian lahan. 


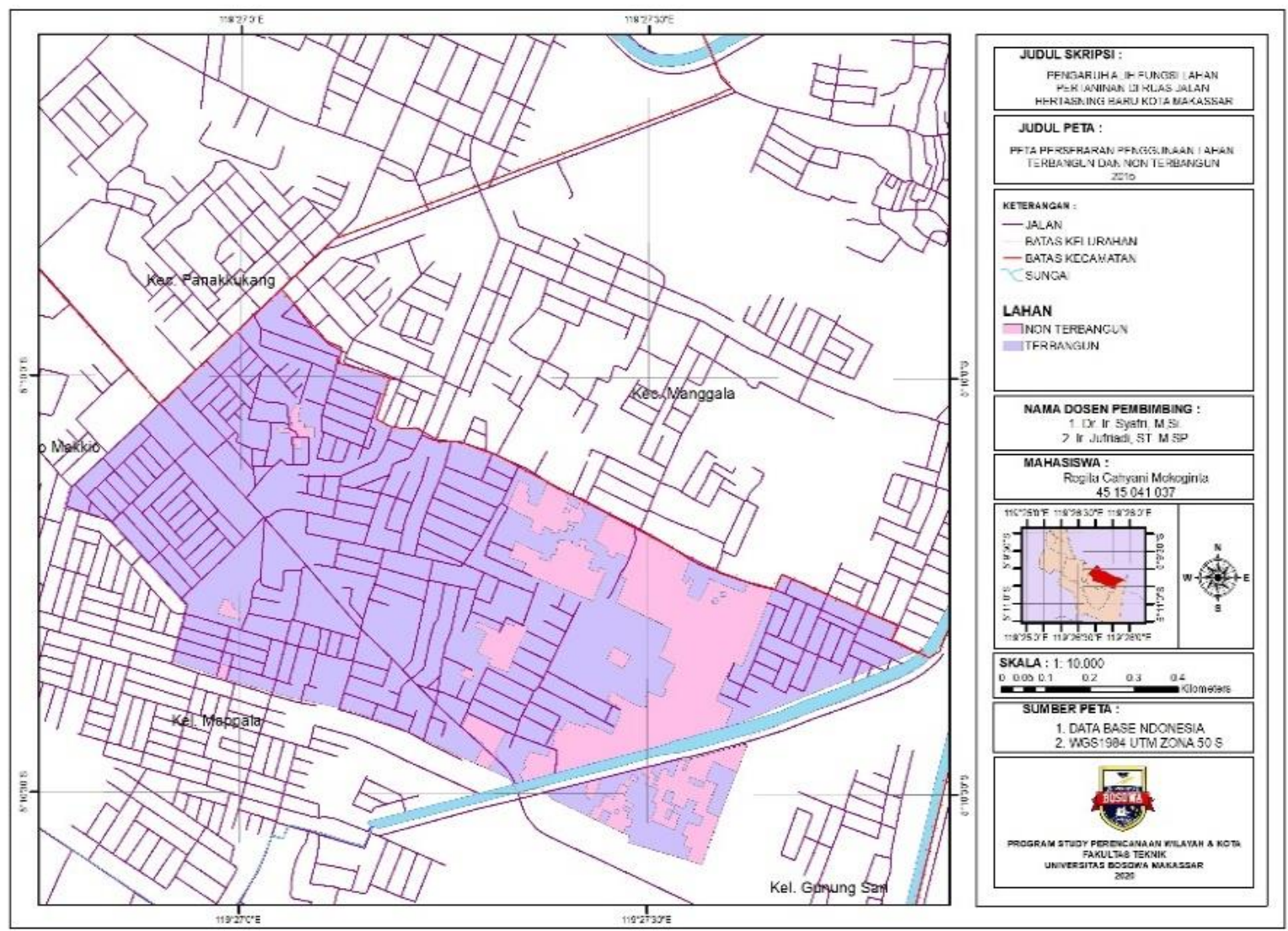

Gambar 2. Peta luas lahan 2015

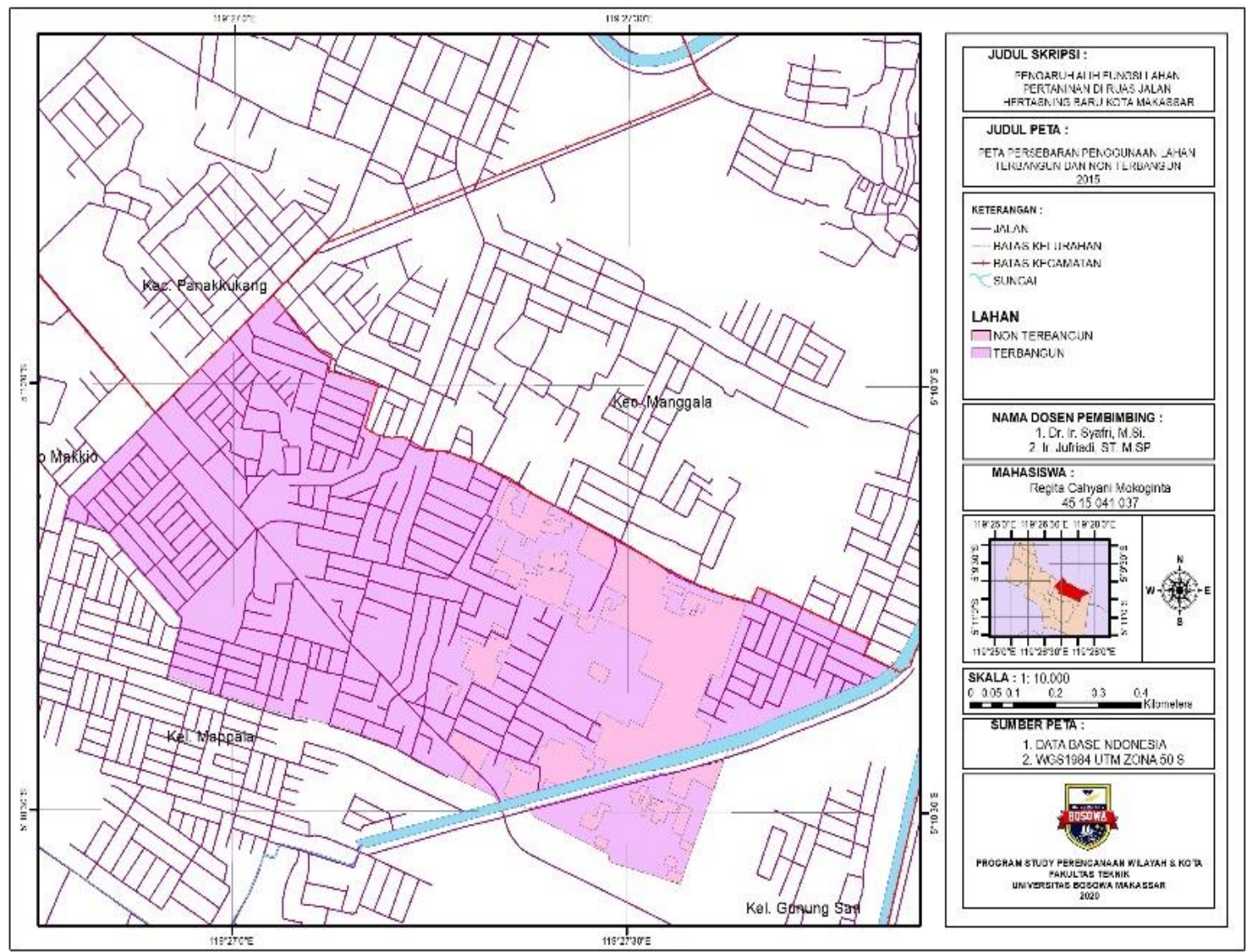

Gambar 3. Peta luas lahan 2018 


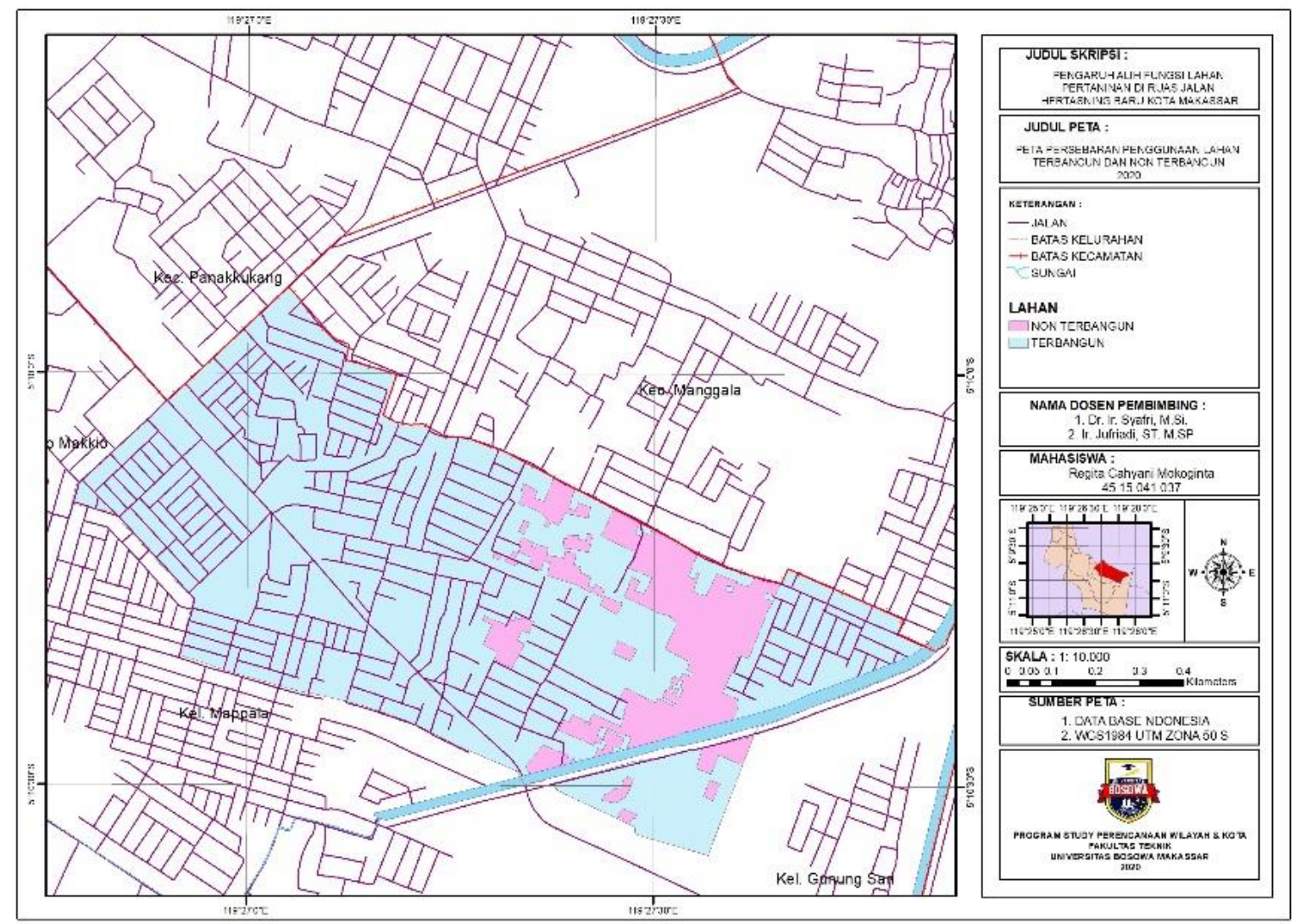

Gambar 4. Peta Luas Lahan 2020

\subsubsection{Analisis Chi kuadrat dan Koefisien Kontingensi C}

a. Pengaruh Alih fungsi lahan terhadap Aktivitas Sosial Ekonomi

Untuk mengetahui bagaimana hubungan antara variabel $\mathrm{X}_{1}$ dan $\mathrm{Y}$ maka digunakan metode analisis Chi Kuadrat berdasarkan hasil kuesioner dengan warga Kelurahan Kassi Kassi. Hasil rekap kuesioner kemudian dimasukkan pada tabel analisis Chi Kuadrat. Untuk lebih jelasnya dapat dilihat pada tabel 1 berikut.

Tabel 1. Analisis Chi Kuadrat Pengaruh Alih fungsi lahan terhadap Aktivitas Sosial Ekonomi

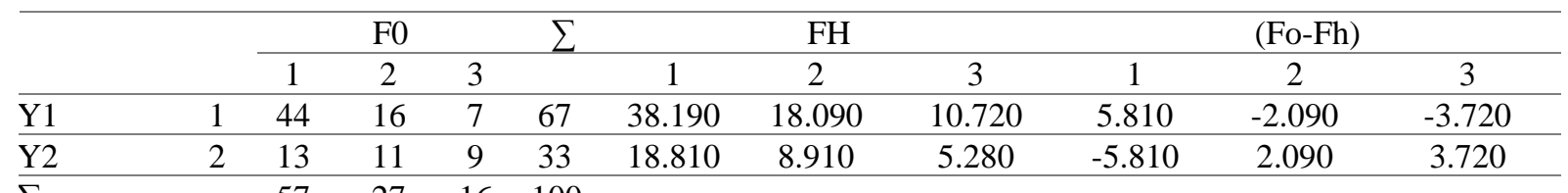

\begin{tabular}{lllll}
\hline$\sum$ & 57 & 27 & 16 & 100
\end{tabular}

$\mathrm{x}^{2}$ hitung

df

$\mathrm{x}^{2}$ tabel

Kesimpulan

Tabel 2. Analisis Decisson Pengaruh Alih fungsi lahan terhadap Aktivitas Sosial Ekonomi

\begin{tabular}{|c|c|c|c|c|c|c|}
\hline \multicolumn{3}{|c|}{$(\mathrm{Fo}-\mathrm{Fh}) 2$} & \multicolumn{3}{|c|}{ (Fo-Fh)2/Fh } & \multirow[t]{2}{*}{$\sum$} \\
\hline 1 & 2 & 3 & 1 & 2 & 3 & \\
\hline 33.756 & 4.368 & 13.838 & 0.884 & 0.241 & 1.291 & 2.416 \\
\hline \multirow[t]{6}{*}{33.756} & 4.368 & 13.838 & 1.795 & 0.490 & 2.621 & 4.906 \\
\hline & & & & & & 7.322 \\
\hline & & & & & & 7.322 \\
\hline & & & & & & 2 \\
\hline & & & & & & 5.991 \\
\hline & & & & & & H0 ditolak \\
\hline
\end{tabular}

Sumber: Hasil Analisis 2020 
Regita Cahyani Mokoginta, Syafri, Jufriadi/ Journal of Urban and Regional Spatial. Vol 01 No 02. Hal 204-214

$$
\boldsymbol{c}=\sqrt{\frac{x^{2}}{x^{2}+n}}=0.26
$$

b. Pengaruh Alih fungsi lahan terhadap pengguna lahan

Untuk mengetahui bgaimana hubungan antara variabel $\mathrm{X}_{2}$ dan $\mathrm{Y}$ maka digunakan metode analisis Chi Kuadrat berdasarkan hasil kuesioner dengan warga Kelurahan Kassi Kassi. Hasil rekap kuesioner kemudian dimasukkan pada tabel analisis Chi Kuadrat. Untuk lebih jelasnya dapat dilihat pada tabel 4.12 berikut.

Tabel 3. Analisis Chi Kuadrat Pengaruh Alih fungsi lahan terhadap pengguna lahan

\begin{tabular}{|c|c|c|c|c|c|c|c|c|}
\hline & & \multicolumn{2}{|c|}{ F0 } & \multirow[t]{2}{*}{$\sum$} & \multicolumn{2}{|c|}{$\mathrm{FH}$} & \multicolumn{2}{|c|}{ (Fo-Fh) } \\
\hline & & 1 & 2 & & 1 & 2 & 1 & 2 \\
\hline Y1 & 1 & 36 & 31 & 67 & 32.160 & 34.840 & 34.840 & 32.160 \\
\hline Y2 & 2 & 12 & 21 & 33 & 15.840 & 17.160 & 17.160 & 15.840 \\
\hline$\sum$ & & 48 & 52 & 100 & & & & \\
\hline \multicolumn{9}{|c|}{$\mathrm{x}^{2}$ hitung } \\
\hline \multicolumn{9}{|l|}{ df } \\
\hline $\mathrm{X}^{2}$ ta & & & & & & & & \\
\hline
\end{tabular}

Kesimpulan

Tabel 4. Analisis Decisson Pengaruh Alih fungsi lahan terhadap pengguna lahan

\begin{tabular}{|c|c|c|c|c|}
\hline \multicolumn{2}{|c|}{$(\mathrm{Fo}-\mathrm{Fh}) 2$} & \multicolumn{2}{|c|}{ (Fo-Fh)2/Fh } & \multirow[t]{2}{*}{$\sum$} \\
\hline 1 & 2 & 1 & 2 & \\
\hline 1213.826 & 1034.266 & 37.743 & 29.686 & 67.429 \\
\hline \multirow[t]{5}{*}{294.466} & 250.906 & 18.590 & 14.622 & 33.212 \\
\hline & & & & 100.641 \\
\hline & & & & 100.641 \\
\hline & & & & 1 \\
\hline & & & & 3.841 \\
\hline
\end{tabular}

H0 ditolak

Sumber: Hasil Analisis, 2020

$$
c=\sqrt{\frac{x^{2}}{x^{2}+n}}=0,708
$$

c. Pengaruh Alih fungsi lahan terhadap aksesibilitas

Untuk mengetahui bagaimana hubungan antara variabel $\mathrm{X}_{3}$ dan $\mathrm{Y}$ maka digunakan metode analisis Chi Kuadrat berdasarkan hasil kuesioner dengan warga Kelurahan Kassi Kassi. Hasil rekap kuesioner kemudian dimasukkan pada tabel analisis Chi Kuadrat. Untuk lebih jelasnya dapat dilihat pada tabel 3 berikut.

Tabel 5. Analisis Chi Kuadrat Pengaruh Alih fungsi lahan terhadap aksesibilitas

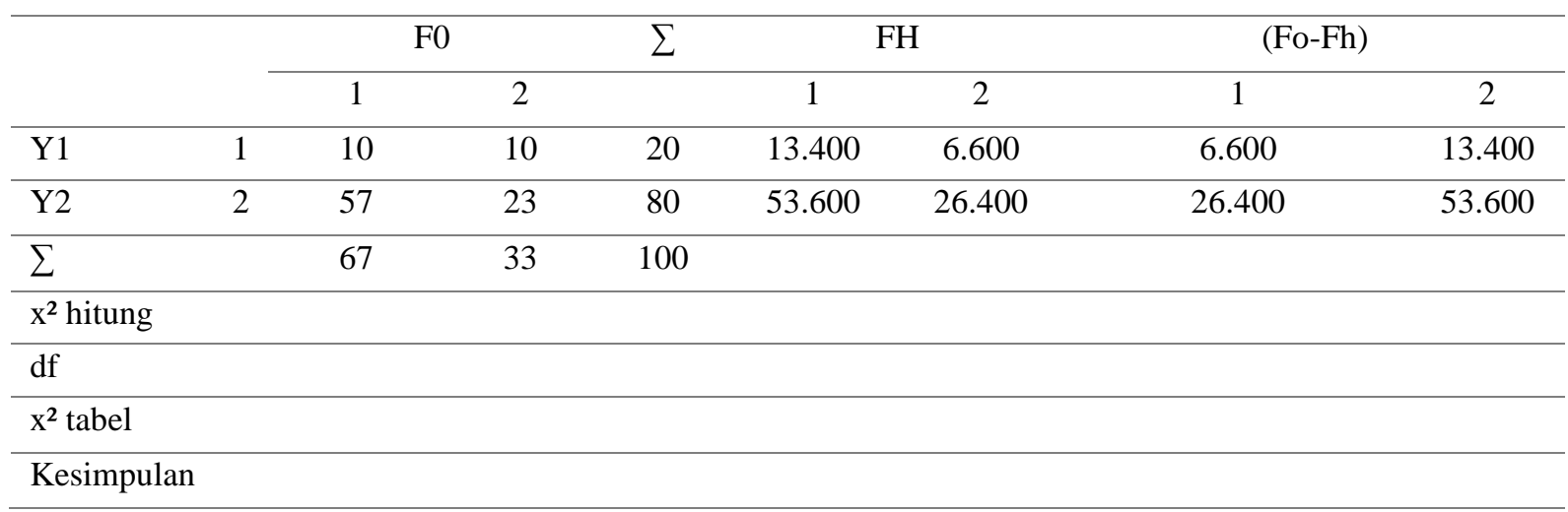


Regita Cahyani Mokoginta, Syafri, Jufriadi/ Journal of Urban and Regional Spatial. Vol 01 No 02. Hal 204-214

Tabel 6. Analisis Decisson Pengaruh Alih fungsi lahan terhadap aksesibilitas

\begin{tabular}{rrrrr}
\hline & (Fo-Fh)2 & & (Fo-Fh) 2/Fh & \multicolumn{1}{c}{} \\
\hline 1 & 2 & 1 & 2 & 30.457 \\
\hline 43.560 & 179.560 & 3.251 & 27.206 & 121.827 \\
\hline 696.96 & 2872.960 & 13.003 & 108.824 & 152.284 \\
\hline & & 152.284 \\
\hline & & 1 \\
\hline
\end{tabular}

Sumber: Hasil Analisis, 2020

$c=\sqrt{\frac{x^{2}}{x^{2}+n}}=0.777$

d. Pemggaruh Alih fungsi lahan terhadap peruntukan ruang

Agar kita dapat mengetahui bagaimana hubungan antara variabel X3 dan Y maka digunakan metode analisis Chi Kuadrat berdasarkan hasil kuesioner dengan warga Kelurahan Kassi Kassi. Hasil rekap kuesioner kemudian dimasukkan pada tabel analisis Chi Kuadrat. Untuk lebih jelasnya dapat dilihat pada tabel 4 berikut.

Tabel 7. Analisis Chi Kuadrat Pemggaruh Alih fungsi lahan terhadap peruntukan ruang

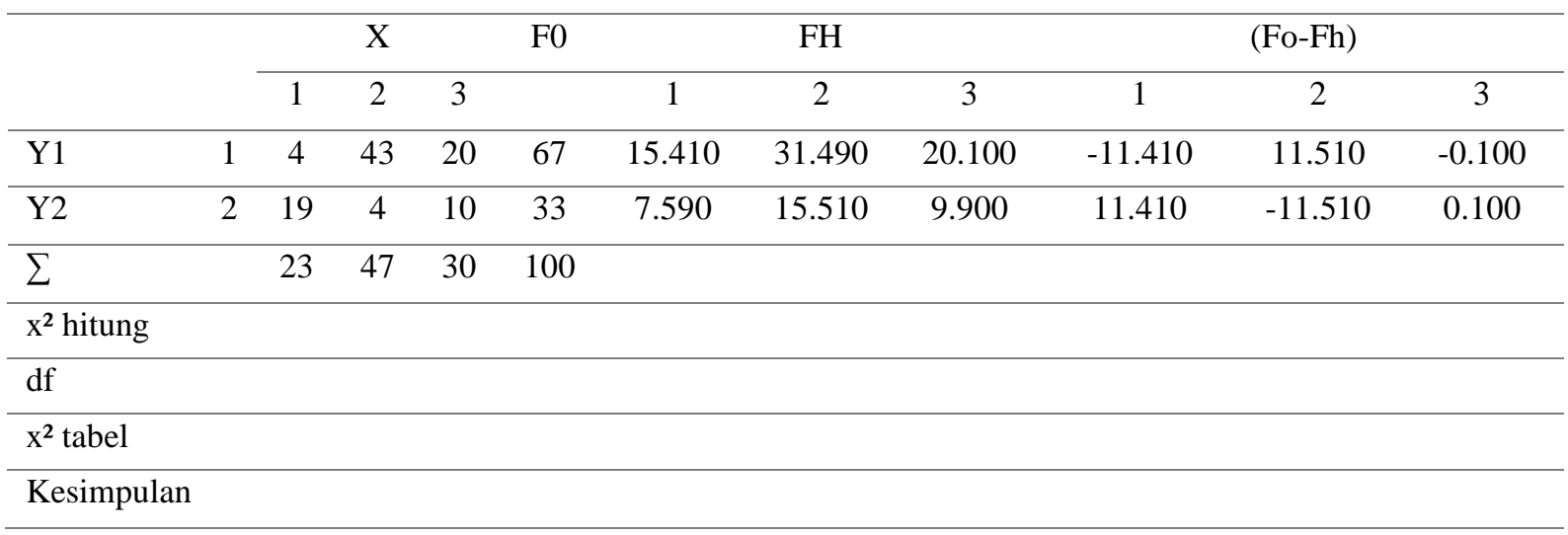

Tabel 8. Analisis Decisson Pengaruh Alih fungsi lahan terhadap aksesibilitas

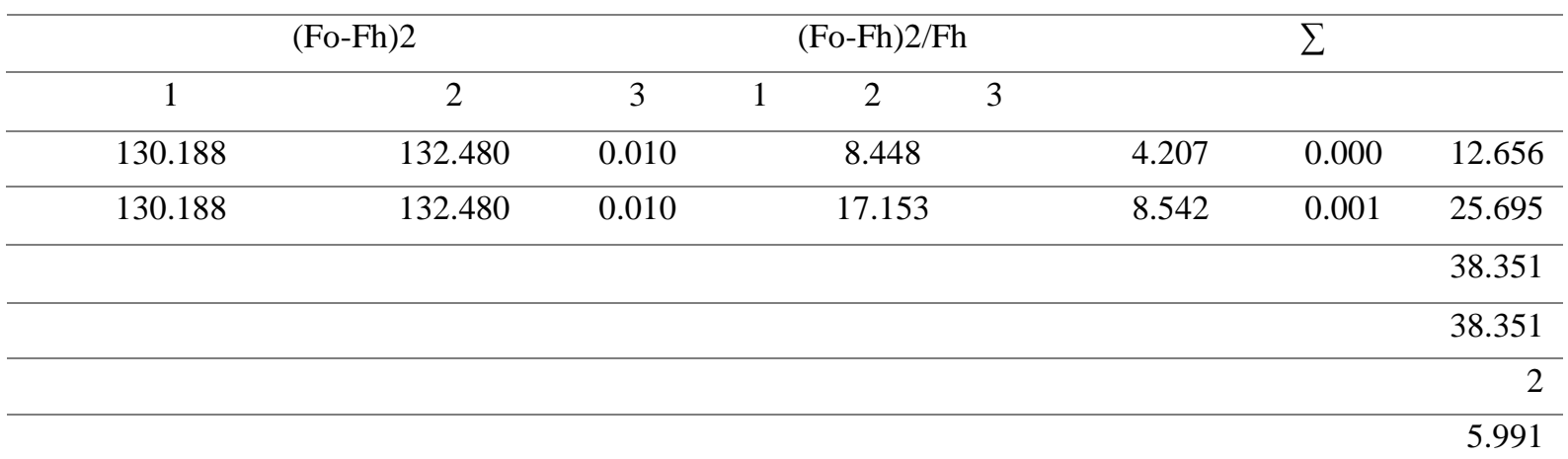

HO ditolak

Sumber: Hasil Analisis, 2020

$$
c=\sqrt{\frac{x^{2}}{x^{2}+n}}=0.53
$$

Berdasarkan hasil uji chi kuadrat dan uji kontingensi maka dapat dirangkum hasil dari pengaruh tiap-tiap variabel $\mathrm{X}$ terhadap Y yang dapat dilihat dari tabel 5 berikut : 
Regita Cahyani Mokoginta, Syafri, Jufriadi/ Journal of Urban and Regional Spatial. Vol 01 No 02. Hal 204-214

Tabel 9. Hasil Analisis Chi Kuadrat setiap variabel

\begin{tabular}{ccccc}
\hline No. & Variabel & Keterangan & $C$ & Pengaruh \\
\hline 1 & $\mathrm{X} 1$ & Aktivitas Sosial Ekonomi & 0,26 & lemah \\
\hline 2 & $\mathrm{X} 2$ & Pengguna Lahan & 0,707 & Kuat \\
\hline 3 & $\mathrm{X} 3$ & Aksebilitas & 0,777 & kuat \\
\hline 4 & $\mathrm{X} 4$ & Peruntukan Ruang & 0,53 & sedang
\end{tabular}

Sumber: Hasil Analisis, 2020

\subsubsection{Analisis SWOT}

Tabel 10. Matriks Internal Strategy Factor Analysis (IFAS)

\begin{tabular}{|c|c|c|c|c|c|}
\hline No. & Faktor Strategis & SP & $\mathrm{K}$ & SP x K & Bobot \\
\hline 1 & $\begin{array}{l}\text { Kekuatan: } \\
\text { Pemakai Lahan }\end{array}$ & 16 & 4 & 64 & 0,37 \\
\hline 2 & Aksesibilitas & 12 & 4 & 48 & 0,26 \\
\hline 3 & Peruntukan Ruang & 16 & 4 & 64 & 0,37 \\
\hline & Jumlah & & & 176 & \\
\hline 4 & $\begin{array}{l}\text { Kelemahan: } \\
\text { Aktivitas Sosial Ekonomi }\end{array}$ & 12 & 4 & 48 & 1 \\
\hline & Jumlah & & & 48 & \\
\hline \multicolumn{6}{|c|}{ Tabel 11. Matriks Nilai Skor IFAS } \\
\hline No. & Faktor Strategis & Bobot & & Rating & $\begin{array}{c}\text { Bobot } \mathrm{x} \\
\text { Rating }\end{array}$ \\
\hline 1 & $\begin{array}{l}\text { Kekuatan: } \\
\text { Pemakai Lahan }\end{array}$ & 0,37 & & 4 & 1,48 \\
\hline 2 & Aksesibilitas & 0,26 & & 3 & 0,78 \\
\hline 3 & Peruntukan Ruang & 0,37 & & 4 & 1,48 \\
\hline & Jumlah & 1 & & & 3,74 \\
\hline 4 & $\begin{array}{l}\text { Kelemahan: } \\
\text { Aktivitas Sosial Ekonomi }\end{array}$ & 1 & & 2 & 2 \\
\hline & Jumlah & 1 & & & 2 \\
\hline
\end{tabular}

Hasil perhitungan dan analisis matriks IFAS (Internal Strategy Factor Analysis) untuk elemen kekuatan dan kelemahan diperoleh dari indeks akumulatif skor kekuatan sebesar 3,74 sedangkan nilai akhir bobot skor elemen kelemahan sebesar 2 .

Tabel 12. Matriks Eksternal Strategy Factor Analysis (EFAS)

\begin{tabular}{|c|c|c|c|c|c|}
\hline No. & Faktor Strategis & SP & $\mathrm{K}$ & $\mathrm{SP} \times \mathrm{K}$ & Bobot \\
\hline 1 & $\begin{array}{l}\text { Peluang: } \\
\text { Undang-Undang No.41 Tahun } 2009 \text { tentang } \\
\text { Perlindungan Lahan Pertanian Pangan } \\
\text { Berkelanjutan }\end{array}$ & 12 & 4 & 48 & 0,3 \\
\hline 2 & $\begin{array}{l}\text { Peraturan Presiden RI No. } 59 \text { Tahun } 2019 \\
\text { tentang Pengendalian Alih Fungsi Lahan } \\
\text { Sawah }\end{array}$ & 12 & 4 & 48 & 0,3 \\
\hline \multirow[t]{2}{*}{3} & $\begin{array}{l}\text { Peraturan Daerah Kota Makassar No. } 4 \\
\text { Tahun } 2015 \text { tentang Rencana Tata Ruang } \\
\text { Wilayah Kota Makassar 2015-2034 }\end{array}$ & 16 & 4 & 64 & 0,4 \\
\hline & Jumlah & & & 160 & \\
\hline 4 & $\begin{array}{l}\text { Ancaman: } \\
\text { Berkembangnya kawasan kumuh }\end{array}$ & 4 & 4 & 16 & 0,25 \\
\hline 5 & Berkurangnya daerah resapan air & 4 & 4 & 16 & 0,25 \\
\hline 6 & $\begin{array}{l}\text { Tidak adanya Pengendalian Harga Tanah } \\
\text { sesuai Arahan Peruntukkan Ruang }\end{array}$ & 8 & 4 & 32 & 0,5 \\
\hline & Jumlah & & & 64 & \\
\hline
\end{tabular}


Tabel 13. Matriks Nilai Skor EFAS

\begin{tabular}{|c|c|c|c|c|}
\hline No. & Faktor Strategis & Bobot & Rating & $\begin{array}{l}\text { Bobot } \mathrm{x} \\
\text { Rating }\end{array}$ \\
\hline 1 & $\begin{array}{l}\text { Peluang: } \\
\text { Undang-Undang No.41 Tahun } 2009 \text { tentang } \\
\text { Perlindungan Lahan Pertanian Pangan } \\
\text { Berkelanjutan }\end{array}$ & 0,3 & 3 & 0,9 \\
\hline 2 & $\begin{array}{l}\text { Peraturan Presiden RI No. } 59 \text { Tahun } 2019 \\
\text { tentang Pengendalian Alih Fungsi Lahan Sawah }\end{array}$ & 0,3 & 3 & 0,9 \\
\hline 3 & $\begin{array}{l}\text { Peraturan Daerah Kota Makassar No. } 4 \text { Tahun } \\
2015 \text { tentang Rencana Tata Ruang Wilayah Kota } \\
\text { Makassar 2015-2034 }\end{array}$ & 0,4 & 4 & 1,6 \\
\hline & Jumlah & 1,0 & & 3,4 \\
\hline 4 & $\begin{array}{l}\text { Ancaman: } \\
\text { Berkembangnya kawasan kumuh }\end{array}$ & 0,25 & 1 & 0,25 \\
\hline 5 & Berkurangnya daerah resapan air & 0,25 & 1 & 0,25 \\
\hline 6 & $\begin{array}{l}\text { Tidak adanya Pengendalian Harga Tanah sesuai } \\
\text { Arahan Peruntukkan Ruang }\end{array}$ & 0,5 & 2 & 1 \\
\hline & Jumlah & 1,0 & & 1,5 \\
\hline
\end{tabular}

\section{Sumber: Diolah tahun 2019}

Hasil perhitungan dan analisis matriks EFAS (Eksternal Strategy Factor Analysis) untuk elemen peluang dan ancaman diperoleh dari indeks akumulatif skor kekuatan sebesar 3,4 sedangkan nilai akhir bobot skor elemen kelemahan sebesar 1,5 .

IFAS dan EFAS diperoleh matriks IE (internal-eksternal) sebagaimana Gambar 4-1:

- $\quad$ (IFAS) Hasil Kekuatan - Kelemahan = 3,74 - 2=1,74

- $\quad$ (EFAS) Hasil Peluang - Ancaman = 3,4 - 1,5 = 1,9

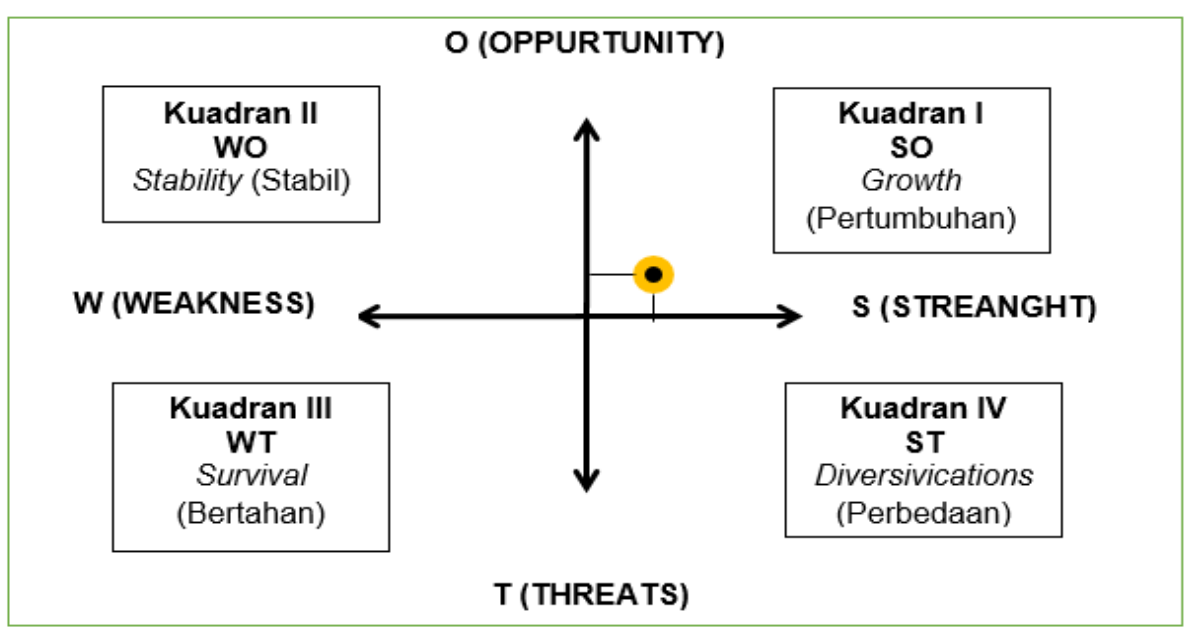

Gambar 4. Kuadran SWOT

Tabel 14. Matriks SWOT Strategi Pengendalian Alih Fungsi Lahan di Ruas Jalan Hertasning Baru Kota Makassar

\begin{tabular}{|c|c|c|c|}
\hline \multicolumn{2}{|l|}{ Faktor Internal } & Kekuatan (S) & Kelemahan $(\mathrm{W})$ \\
\hline & & 1. Pemakai Lahan & 1. Aktivitas Sosial Ekonomi \\
\hline \multirow{2}{*}{\multicolumn{2}{|c|}{ Faktor Eksternal }} & 2. Aksesibilitas & \\
\hline & & 3. Peruntukan Ruang & \\
\hline \multicolumn{2}{|l|}{ Peluang (O) } & Strategi S-O & \multirow{8}{*}{$\begin{array}{l}\text { Strategi W-O } \\
\text { (Turn Arround Strategies) } \\
\text { 1. Memanfaatkan UU No.41 Tahun } \\
2009 \text { untuk mengendalikan } \\
\text { perkembangan aktivitas sosial } \\
\text { ekonomi dalam pengontrolan alih } \\
\text { fungsi lahan di ruas jalan } \\
\text { Hertasning Baru }\end{array}$} \\
\hline 1. Undang-Undang & No.41 & (Aggresive Strategies) & \\
\hline Tahun 2009 & tentang & 1. Memanfaatkan Pemakai Lahan & \\
\hline Perlindungan & Lahan & untuk menjaga keberlanjutan & \\
\hline Pertanian & Pangan & lahan pertanian masih produktif & \\
\hline Berkelanjutan & & dengan memberikan intensif & \\
\hline \multirow{2}{*}{\multicolumn{2}{|c|}{$\begin{array}{l}\text { 2. Peraturan Presiden RI No. } \\
59 \text { Tahun } 2019 \text { tentang }\end{array}$}} & kepada pemilik lahan. & \\
\hline & & & \\
\hline
\end{tabular}




\section{Pengendalian Alih Fungsi Lahan Sawah}

3. Peraturan Daerah Kota Makassar No. 4 Tahun 2015 tentang Rencana Tata Ruang Wilayah Kota Makassar 2015-2034
2. Memanfaatkan ruang sepanjang jalan hertasning untuk peruntukan ruang non pertanian secara terbatas

3. Memaksimalkan peruntukan ruang sesuai dengan arahan rencana tata ruang wilayah

2. Memanfaatkan Perpres No 59 Tahun 2019 untuk pengendalian aktivitas sosial ekonomi dalam pengontrolan alih fungsi lahan di ruas jalan Hertasning Baru

3. Memanfaatkan Perda Kota Makassar No. 4 tahun 2015 dalam pengendalian perkembangan aktivitas sosial ekonomi sesuai dengan peruntukannya dengan memberikan insentif dan disinsentif.

\begin{tabular}{l}
\hline Ancaman (T) \\
1. Berkembangnya kawasan \\
kumuh \\
2. Berkurangnya daerah \\
resapan air \\
3. Tidak \\
Pengendalian ranya \\
Tanah sesuai Arahan \\
\multicolumn{2}{l}{ Peruntukkan Ruang }
\end{tabular}

Hasil: Analisis tahun 2020

\section{Strategi S-T}

(Divensification Strategies)

1. Memanfaatkan pemakai lahan dengan memberikan sosialisasi tentang program arah pemanfaatan ruang untuk menghindari perkembangan kawasan kumuh

2. Memanfaatkan aksesibilitas ruas jalan Hertasning Baru dengan memberikan jalur hijau untuk menambah daerah resapan air

3. Memanfaatkan peruntukan ruang yang sesuai dengan peraturan perundang-undangan dan daerah terkait Tata Ruang untuk pengendalian harga tanah
Strategi W-T

(Defensive Strategies)

1. Mengatur perkembangan aktivitas sosial ekonomi sesuai dengan arah peruntukan pemanfaatan ruang untuk menghindari perkembangan kawasan kumuh

2. Mengatur perkembangan aktivitas sosial ekonomi dengan mengatur KDB bangunan untuk menjaga daerah resapan air

3. Mengatur perkembangan aktivitas sosial ekonomi untuk menjaga stabilitas harga tanah

\section{KESIMPULAN}

Berdasarkan hasil penelitian dan pembahasan yang telah dilakukan dapat ditarik kesimpulan, Pengaruh Alih fungsi lahan terhadap pemakai lahan kuat, Pengaruh Alih fungsi lahan terhadap aksesibilitas kuat, Pengaruh Alih fungsi lahan terhadap peruntukan ruang sedang, dan Pengaruh Alih fungsi lahan terhadap sosial ekonomi lemah. Berdasarkan hasil analisis SWOT dapat disimpulkan bahwa strategi yang akan digunakan untuk pengendalian alih fungsi lahan pertanian adalah strategi SO. Adapun rumusan strateginya yaitu Memanfaatkan Pemakai Lahan untuk menjaga keberlanjutan lahan pertanian masih produktif dengan memberikan intensif kepada pemilik lahan, Memanfaatkan ruang sepanjang jalan hertasning untuk peruntukan ruang non pertanian secara terbatas dan Memaksimalkan peruntukan ruang sesuai dengan arahan rencana tata ruang wilayah

\section{DAFTAR PUSTAKA}

Anwar Hidayat, (2012) Tutorial Rumus Chi Square Dan Metode Hitung

Anwar Hidayat, (2012) Penjelasan Koefisien Kontingensi C dan Cara Hitung

Aryunto, P. (2011) Pengaruh Perkembangan Ekonomi Kota terhadap Struktur Ruang Kota (Studi Kasus Kabupaten

Gresik). Jurnal Institut Teknologi Sepuluh November , 1-15.

VhavgoD. (2011) Analisis SWOT 